\title{
The life history of Pygidiopsis macrostomum Travassos, 1928 (Digenea: Heterophyidae)
}

\author{
Susana Balmant Emerique Simões' ${ }^{1}$, Helene Santos Barbosa ${ }^{2}$, Cláudia Portes Santos ${ }^{1 /+}$ \\ 'Laboratório de Avaliação e Promoção da Saúde Ambiental '2aboratório de Biologia Estrutural, Instituto Oswaldo Cruz-FIOCRUZ, \\ Av. Brasil 4365, 21045-900 Rio de Janeiro, RJ, Brasil
}

The life history of the trematode Pygidiopsis macrostomum Travassos, 1928 is described for the first time. Rediae and cercariae were obtained from naturally infected snails Heleobia australis (d'Orbigny), a new first intermediate host. Metacercariae were found encysted in the mesenteries of three naturally infected guppies, Phalloptychus januarius (Hensel), Jenynsia multidentata (Jenyns) (new host records) and Poecilia vivipara Bloch and Schneider. Experimental infections were successfully completed in the intermediate hosts $\mathrm{H}$. australis and Poe. vivipara reared in the laboratory and hamsters Mesocricetus auratus Waterhouse were utilised as a definitive host.

Key words: Pygidiopsis macrostomum - Heterophyidae - Digenea - Heleobia australis - Poecilia vivipara - life cycle

Pygidiopsis macrostomum Travassos, 1928, originally described based on a single specimen from Rattus norvegicus (Erxleben) in Brazil, has also been reported from a piscivorous bat, Noctilio leporinus mastivus $\mathrm{Ri}$ beiro, in Cuba (Odening 1969, Zdzitowiecki \& Rutkowska 1980). We have previously redescribed this species from the holotype and adults obtained from hamsters Mesocricetus auratus Waterhouse experimentally infected with metacercariae from naturally infected guppies Poecilia vivipara Bloch and Schneider taken from Rodrigo de Freitas Lagoon in Rio de Janeiro (RJ), Brazil (Simões et al. 2005). However, other aspects of the life history and biology of this species, especially in relation to the first intermediate host, still need to be elucidated. In this work, the life cycle was completed under laboratory conditions and we provide new host records along with the first descriptions of the redia and cercaria.

\section{MATERIALS AND METHODS}

The guppies Poe. vivipara, Phalloptychus januarius (Hensel) and Jenynsia multidentata (Jenyns) were collected on the edge of the Rodrigo de Freitas Lagoon, RJ, Brazil (22 $57^{\prime} 2^{\prime \prime} S$, 4311'9'W) and examined for metacercariae. A hydrobiid snail, Heleobia australis (d'Orbigny), was collected in the same lagoon and examined for cercariae. Poe. vivipara and H. australis were reared in the laboratory in filtered lagoon water to provide specimens devoid of infection.

Two experimental infections (summer and winter) were performed. For each experiment, one hamster $M$. auratus was fed with the mesenteries of four naturally infected Poe. vivipara and, on the fourth day postinfection (dpi) each was examined for ovigerous adults of Pyg. macrostomum.

Financial support: FAPERJ, PAPESV/FIOCRUZ

+ Corresponding author: cpsantos@ioc.fiocruz.br

Received 17 October 2008

Accepted 26 December 2008
Two uninfected stocks of snails (summer and winter) were exposed to infection by placing the eggs of adult Pyg. macrostomum, obtained experimentally from hamsters in their aquaria. Laboratory-reared Poe. vivipara (4 in each experiment for summer and winter) were exposed to cercariae obtained from these experimentally infected $H$. australis. One hamster for each experiment was fed with the mesenteries of the experimentally infected fish and later examined at four dpi for adults of Pyg. macrostomum.

All larval stages and adults were studied live, with or without vital stains. Semi-permanent slides were prepared in glycerine jelly (Moravec 1994) and glycerine/picric acid (Ergens 1969). Other specimens were fixed in $70 \%$ alcohol or hot $4 \%$ formaldehyde solution, stained with Gomori's trichrome or alcoholic chloridric carmine, cleared in beechwood creosote and mounted in Canada balsam. Illustrations were made with the aid of a drawing attachment on a Leica DM LS2 microscope. Measurements are presented as the range, with the mean in parentheses.

For scanning electron microscopy (SEM), specimens were fixed for $1 \mathrm{~h}$ at $\mathrm{rt}$ with $2.5 \%$ glutaraldehyde in 0.1 M Na-cacodylate buffer and washed in the same buffer. Specimens were post-fixed for $3 \mathrm{~h}$ at $\mathrm{rt}$ in a solution of $1 \%$ osmium tetroxide in $0.1 \mathrm{M} \mathrm{Na}$-cacodylate buffer, dehydrated in an ascending acetone series, dried by criticalpoint method with $\mathrm{CO}_{2}$, and sputter-coated to a thickness of $20 \mathrm{~nm}$ with gold. The samples were examined using a Jeol JSM-6390LV scanning electron at an accelerating voltage of $15 \mathrm{kV}$.

\section{RESULTS \\ Pygidiopsis macrostomum Travassos, 1928}

(Figs 1, 2)

Adult (Fig. 1A) (measurements based on 9 specimens obtained experimentally): Body pyriform, 667-816 $\times 292$ $400(759 \times 354)$. Tegument spinose. Oral sucker 76-104 $\times$ 95-123 $(95 \times 109)$ without oral spines. Ventral sucker $66-95 \times 76-95(85 \times 87)$ at mid-body. Sucker width ratio 

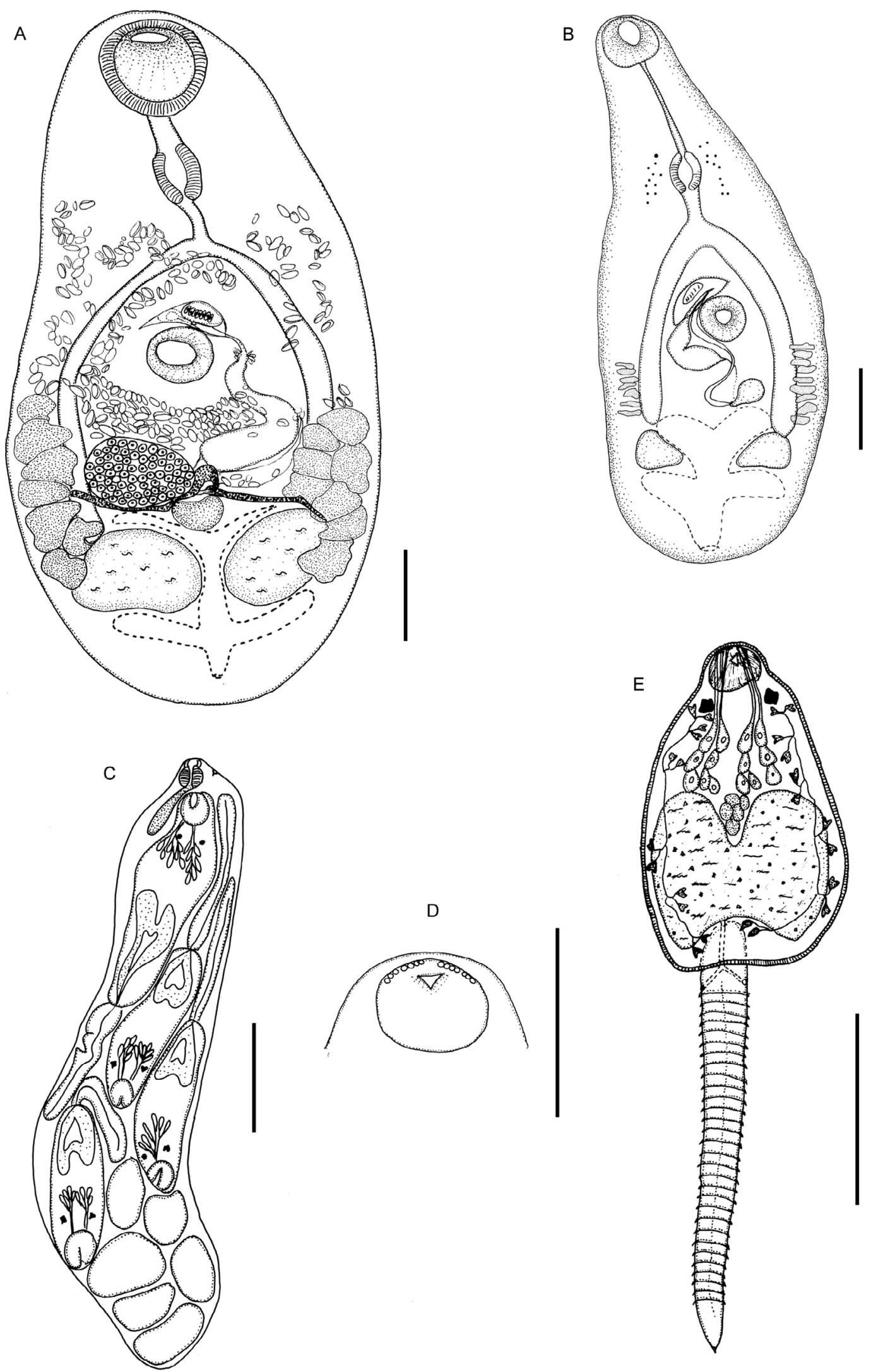

Fig. 1: Pygidiopsis macrostomum, light microscopy. A: ventral view of adult from experimentally infected hamster; B: dorsal view of metacercaria from naturally infected Poecilia vivipara; C: redia from experimentally infected Heleobia australis; D: detail of oral sucker of cercaria with pores of penetration glands; E: cercaria shed from experimentally infected H. australis, in ventral view. Scale bars: A-E: $100 \mu \mathrm{m}$. 
1:0.6-1.0 (0.8). Prepharynx 29-76 (54); pharynx 57-86 × 48-66 $(67 \times 54)$. Esophagus 29-57 (39) long. Intestinal ceca blind, reaching to testicular level. Testes symmetrical, slightly irregular in shape, close to posterior end of body: left $69-100 \times 118-150(83 \times 128)$, right $73-100$ $\times 92-146(84 \times 131)$. Seminal vesicle sigmoid, posterosinistral to ventral sucker; ejaculatory duct opens into genital sac. Genital sac anterosinistral to ventral sucker, contains muscular oval gonotyl, $23-28 \times 32-51(24 \times 44)$. Ovary dextral, $69 \times 69-123(64 \times 94)$ anterior to right testis. Seminal receptacle 43-100 × 60-114 $(75 \times 85)$. Vitellarium forms two lateral bands of seven-nine follicles extending between level of testes and ventral sucker. Uterus sinuous, extends from level of pharynx to level of anterior region of testes. Fully-developed eggs operculate, $18-21 \times 11(20 \times 11)(\mathrm{n}=18)$. Excretory vesicle branched, X-shaped, with lateral arms anterior and posterior to testes; pore terminal.

Host - M. auratus, hamsters, experimentally infected.

Site - Intestine.

Metacercaria (Fig. 1B) (measurements based on 10 specimens from experimentally infected Poe. vivipara at $18 \mathrm{dpi}$ ): Cyst round, thin-walled, translucent, 431-492 $\times$ 431-492 $(469 \times 469)$. Body of excysted metacercaria pyriform, $541-760 \times 209-446(667 \times 299)$. Tegument spinose back to testicular level. Cercarial eyespot pigment scattered at level of pharynx. Oral sucker terminal, $55-123 \times 73-132(89 \times 100)$. Ventral sucker at mid-body, $51-100 \times 51-100(72 \times 73)$. Sucker width ratio 1:0.6-0.9 (0.8). Prepharynx 46-123 (74); pharynx 46-73 × 28-60 $(55 \times 46)$. Esophagus 18-64 (34) long; intestinal ceca reach to testicular level. Testes symmetrical, near posterior extremity: left 55-109 $\times$ 55-118 $(74 \times 89)$, right $46-118 \times 46-118(73 \times 76)$. Genital sac anterosinistral to ventral sucker contains muscular gonotyl, 18-23 × 41-46 $(21 \times 42)$. Ovary dextral, $23-37 \times 23-60(30 \times 39)$. Vitellarium lateral with seven-nine follicles in each side. Excretory vesicle branched, X-shaped, with lateral arms anterior and posterior to testes; pore terminal.

Host - Poe. vivipara naturally and experimentally infected. Pha. januarius (new host record) and J. multidentata (new host record), naturally infected.

Site of infection - Encysted in mesentery.

Cercaria (Figs 1D-E, 2A-F) (measurements based on 10 fully-developed specimens shed from experimentally infected snail, heat-killed in paraformaldehyde): Pleurolophocercous. Living cercaria with globose body, 155 $179 \times 137-146(161 \times 141)($ Fig. 2A-B). Tegument spinose (Fig. 2C-D). Brown pigment scattered throughout body. Tail longer than body proper, 256-265 (262), deeply inserted dorsally into tail socket, with small ventro-terminal fin-fold (visible only using SEM) (Fig. 2E-F). Tail margins annulated. Oral sucker spherical, 21-25 × 32-34 $(23 \times 33)$ (Fig. 2C). No acicular spines at anterior end. Pair of rectangular eye-spots present. Seven pairs $(4+3)$ of unicellular penetration glands at mid-body; their ducts pass forward in four groups to open via four groups
(3-4-4-3) of pores at anterior extremity (Fig. 1D-E). Esophagus and ceca not differentiated. Pharynx small. Vestigial cells in region of ventral sucker. Genital primordium situated immediately anterior to excretory vesicle. Flame-cell formula $2[(2+2+2)(2+2+2)]=24$. Excretory vesicle large, with thick epithelial wall and narrow stem which bifurcates in base of tail; pores lateral at base of tail.

Host $-H$. australis, naturally and experimentally infected (new host record).

Redia (Fig. 1C) (measurements based on 10 specimens): Body a thin-walled sac without appendages, $560-691 \times 95-142(605 \times 114)$, filled with germinal balls and developing cercariae. Pharynx 23-28 $\times 23(26 \times 23)$. Birth pore at level of pharynx.

Host - H. australis (d'Orbigny), naturally and experimentally infected (new host record).

\section{Site of infection - Gonads.}

Experimental infection - No hatching miracidia were observed. The snails ingested eggs and the shedding of cercariae started $34 \mathrm{dpi}$ in the summer and $56 \mathrm{dpi}$ in the winter experiments. Cercarial release continued for 22 months (end of experiment). Of 30 cercariae used to infect each Poe. vivipara (4 in each experiment), seven, eight, 10 and 11 metacercariae were recovered 18 dpi in summer. In the winter experiment, seven, eight, nine and 11 metacercariae were recovered at $21 \mathrm{dpi}$. Adults with eggs were recovered from all hamsters at four dpi.

Life history and biology - Pyg. macrostomum has a three-host life-cycle: a snail first intermediate host $(H$. australis), fish second intermediate hosts (Poe. vivipara, Pha. januarius and J. multidentata) and various mammals (indicated by successful experiments with hamsters and previous records) as definitive hosts.

The eggs of Pyg. macrostomum are released within the faeces of the mammalian host and may fall directly into or are carried into the water of the lagoon. The eggs are ingested by the snail $H$. australis and, within its gonads, the miracidia are likely transformed into sporocysts within which rediae develop. Cercariae are formed within the rediae and are released via the birth pore. The shedding of cercariae starts 34-56 dpi and continues for an indefinite period.

The cercariae alternate periods of swimming and resting. Swimming movements include several small, stepped leaps, both ascending and descending, induced by movement of the tail. On the bottom, the tail curves alongside the body, causing the body to spin laterally around its own axis in either a clockwise or anti-clockwise direction; this is followed by a period of rest with just half of the tail folded alongside the body.

The cercariae are likely ingested by the second intermediate hosts, cyprinodontiform fishes and metacercariae encyst in the mesenteries. Small mammals feed on the cyprinodontiform fishes, enabling the infection by metacercariae and their development to the adult stage in the intestine of these hosts. 


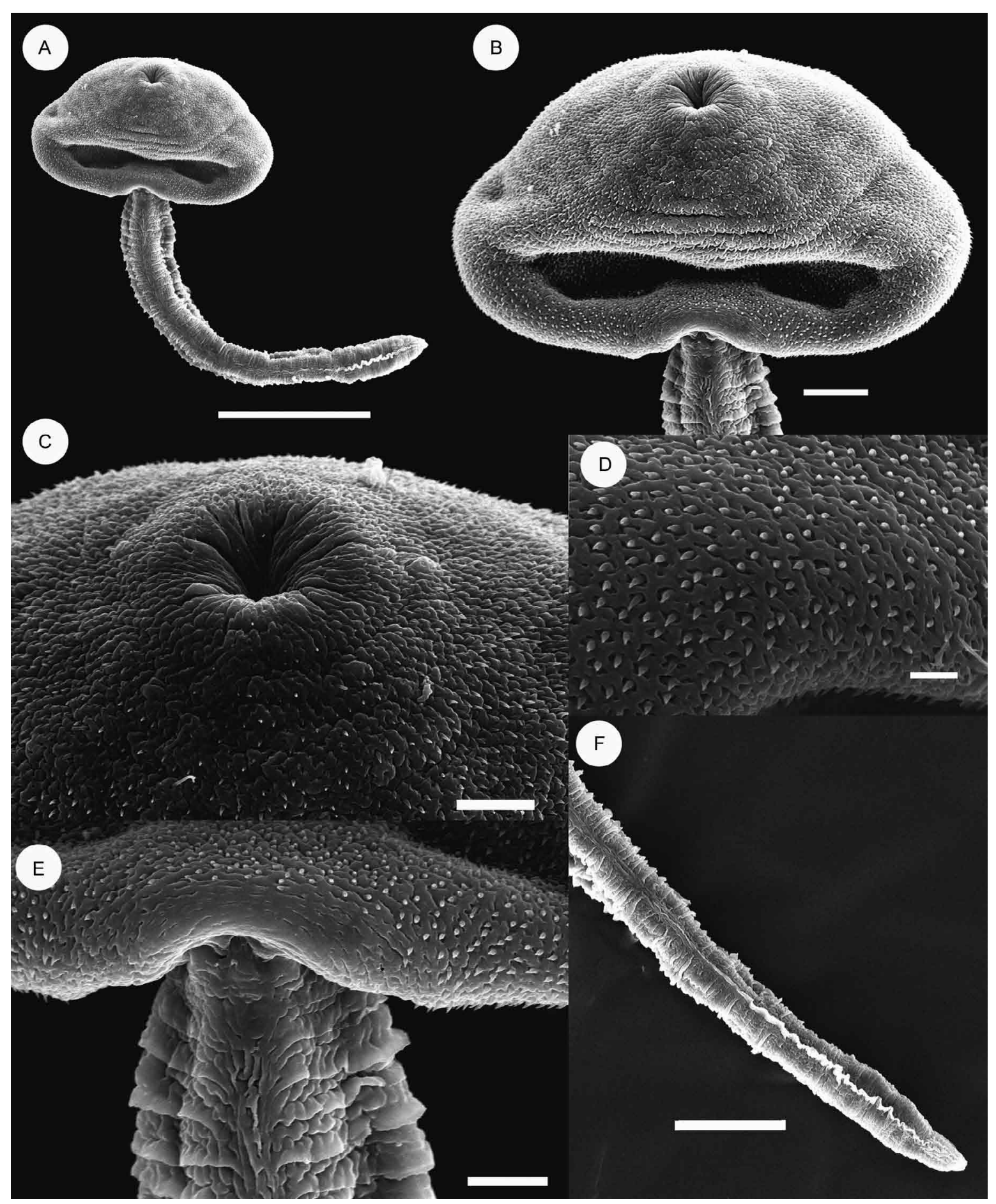

Fig. 2: cercaria of Pygidiopsis macrostomum, SEM micrographs. A: body with long tail, ventral view; B: body with ventral depression; C: anterior end with oral sucker, tegument spined; D: detail of single-pointed spines; E: insertion of tail on smooth area of dorsal side of body, ventral side of body extremity with spines; F: terminal region of tail with small ventral alae. Scale bars: A: $50 \mu \mathrm{m}$; B: $10 \mu \mathrm{m}$; C, E: $5 \mu \mathrm{m} ; \mathrm{D}: 2 \mu \mathrm{m}$; F: $20 \mu \mathrm{m}$.

\section{DISCUSSION}

Pyg. macrostomum has been reported to parasitise mammals, such as the rat $R$. norvegicus and the bat $N$. leporinus mastivus in South America and the West Indies (Travassos 1928, Odening 1969, Zdzitowiecki \& Rutkowska 1980) and it has been shown by us to infect hamsters in the laboratory (Simões et al. 2005). In the latter report, we redescribed this parasite using light and SEM, based on the holotype and adults experimentally obtained in hamsters, with additional data on the metacercaria. However, prior to the present study, the biology of the parasite and its molluscan intermediate hosts were unknown. 
Data on the life cycles of Pygidiopsis spp. have been reported for Pygidiopsis genata Looss and Pygidiopsis summa Onji and Nishio (see Yamaguti 1975), Pygidiopsis ardeae Køie (see Køie 1990a), Pygidiopsis crassus Ostrowski de Núñez (see Ostrowski de Núñez 1995) and Pyg. australis Ostrowski de Núñez (see Ostrowski de Núñez 1996). The life cycle of Ascocotyle (Phagicola) pindoramensis (Travassos) (see Ostrowski de Núñez 1976) needs to be re-evaluated, as in another paper we have transferred this species to another genus and have suggested that their specimens may belong to a different species (Simões et al. 2006).

Sporocysts of Pyg. macrostomum were not observed in naturally and experimentally infected $H$. australis, but the redia and cercaria are described here for the first time. The redia of Pyg. macrostomum containing cercariae is larger than that of the most closely related species, Pyg. crassus (i.e. 605 vs. $376 \mu$ m) (Ostrowski de Núñez 1995). Cercaria of both species possess seven pairs $(3+4+4+3)$ of penetration glands and an identical flame-cell formula $2[(2+2+2)+(2+2+2)]=24$, but differ in the size of tail, which is smaller in Pyg. macrostomum (262 vs. $327 \mu \mathrm{m})$.

The cercariae of Pyg. macrostomum are of the pleurolophocercous type, i.e. they are ocellate; the tail lacks furcae, is longer than the body proper and possesses a median dorso-ventral fin-fold; the ventral sucker is apparently absent or vestigial; the excretory vesicle is Xshaped (bilobed), with a thick-walled, epithelial lining; and they develop in rediae (Schell 1970, Galaktianov \& Dobrovolskij 2003). The ultrastructure of the cercaria of Pyg. macrostomum studied herein showed it possesses a small ventro-terminal fin-fold, not seen using light microscopy, and the tegumental spines are single-pointed, thus differing from the wide, flat and brush-shaped tegumental spines we previously observed in the metacercaria and adults (Simões et al. 2005). The cercaria of $P y g$. ardeae differs from that of Pyg. macrostomum in the presence of five pre-oral hooklets (Køie 1992), while Pyg. genata and Pyg. summa may be differentiated by the presence of a conspicuous lateral ala on the tail (Ostrowski de Núñez 1996).

The continuous production of rediae, resulting in the uninterrupted release of cercariae for several months observed in Pyg. macrostomum, has already been reported for other trematode species (Lundahl 1941, Greer \& Corkum 1979, Cribb 1986, Simões et al. 2008). In our experiment, the snails were infected only once with eggs of Pyg. macrostomum and the shedding of cercariae began at $34 \mathrm{dpi}$ and persisted for 22 months until the end of the experiment. The possibility of multiple infections as an explanation for this continuous production of cercariae from rediae is excluded based on our experimental system. Therefore, our data strongly suggest that the sporocysts may have the capacity to multiply germinal cells for the permanent production of rediae, and thus cercariae, as long as the snail host lives (Galaktianov \& Dobrovolskij 2003). This may also be a more likely explanation for Acanthocollaritrema umbilicatum Travassos (Cryptogonimidae), whose life cycle we have discussed in relation to the possibility that there might be more than two generations of rediae (Simões et al. 2008).
In RJ, Brazil, pleurolophocercous cercariae have been previously reported from Heleobia sp. by Thiengo et al. (2004, 2006), but without a formal specific indication. The life cycle of the majority of species of Pygidiopsis include gastropods of the family Hydrobiidae as first intermediate hosts, but Pyg. genata and Pyg. summa were reported to develop in members of the Thiaridae and Potamididae, respectively (Køie 1990b, Ostrowski de Núñez 1996). In the studied area, $H$. australis is a natural intermediate host of both A. umbilicatum (Simões et al. 2008) and Pyg. macrostomum.

This is first study of the life history of Pyg. macrostomum, with descriptions of the redia, cercaria and metacercaria, and reports of the natural first and second intermediate hosts. The establishment of successful experimental infections also enhances our knowledge of the biology of this trematode under natural and experimental conditions.

\section{ACKNOWLEDGEMENTS}

To Dr. Dely Noronha and Dr. Luis Muniz, Helminthological Collection of the Instituto Oswaldo Cruz-Fiocruz, Rio de Janeiro, kindly provided the specimens for study.

\section{REFERENCES}

Cribb T 1986. The life cycle and morphology of Stemmatostoma pearsoni, gen. et sp. nov., with notes on the morphology of Telogaster opisthorchis Macfarlane (Digenea: Cryptogonimidae). Aust J Zool 34: 279-304.

Ergens R 1969. The suitability of ammonium picrate-glycerin in preparing slides of lower Monogenoidea. Folia Parasitol 44: 320.

Galaktionov KV, Dobrovolskij AA 2003. The biology and evolution of trematodes. An essay on the biology, morphology, life cycles, transmissions, and evolution of digenetic trematodes, Kluwer Academic Publishers, Dordrecht, 592 pp.

Greer GJ, Corkum KC 1979. Life cycle of three digenetic trematodes, including descriptions of two new species (Digenea: Cryptogonimidae). Proc Helminthol Soc Wash 46: 188-200.

Køie M 1990a. The life cycle of Pygidiopsis ardeae Køie, 1990 (Digenea: Heterophyidae). J Parasitol 76: 537-541.

Køie M 1990b. Pygidiopsis ardeae n. sp. (Digenea: Heterophyidae: Pygidiopsinae) in the grey heron Ardea cinerea L. from Denmark. Syst Parasitol 15: 141-149.

Køie M 1992. Scanning electron microscopy of cercariae, metacercariae and adults of Pygidiopsis ardeae Køie, 1990 (Digenea: Heterophyidae). Parasitol Res 78: 469-474.

Lundahl WS 1941. Life history of Caecincola parvulus Marshall and Gilbert (Cryptogonimidae, Trematoda) and the development of its excretory system. Trans Amer Micros Soc 60: 461-184.

Moravec F 1994. Parasitic nematodes of freshwater fishes of Europe, Kluwer Academic Publishers, Prague, 510 pp.

Odening K 1969. Exkretionssystem und systematische Stellung kubanischer Fledermaustrematoden. Bijdr Dierk 39: 45-62.

Ostrowski de Núñez M 1976. Fauna de agua dulce de la Republica Argentina. VI. Las cercarias de Ascocotyle tenuicollis Price 1935 y de Pygidiopsis pindoramensis Travassos, 1929 (Trematoda: Heterophyidae). Physis B 34: 51-57.

Ostrowski de Núñez M 1995. Life history studies of Pygidiopsis crassus n. sp. (Trematoda: Digenea: Heteropyidae) in the Neotropical Region. Mem Inst Oswaldo Cruz 90: 13-19. 
Ostrowski de Núñez M 1996. Life history studies of heterophyid trematodes in the Neotropical Region: Pygidiopsis australis $\mathrm{sp}$. n., a sibling species of $P$. pindoramensis Travassos, 1929. Acta Parasitol 41: 13-19.

Schell SC 1970. The Trematodes, WM.C. Brown Company Publishers, Dubuque, 355 pp.

Simões SBE, Barbosa HS, Santos CP 2005. Redescription and surface ultrastructure of Pygidiopsis macrostomum (Digenea: Heterophyidae). J Parasitol 91: 931-936.

Simões SBE, Neves RFC, Santos CP 2008. Life history of Acanthocollaritrema umbilicatum Travassos, Freitas and Bührnheim, 1965 (Digenea: Cryptogonimidae). Parasitol Res 103: 523-528.

Simões SBE, Scholz T, Barbosa HS, Santos CP 2006. Taxonomic status, redescription, and surface ultrastructure of Ascocotyle (Phagicola) pindoramensis n. comb. (Digenea: Heterophyidae). J Parasitol 92: 501-508.
Thiengo SB, Mattos AC, Boaventura MF, Loureiro MS, Santos SB, Fernandez MA 2004. Freshwater snails and schistosomiasis mansoni in the state of Rio de Janeiro, Brazil: V- Norte Fluminense Mesoregion. Mem Inst Oswaldo Cruz 99 (Suppl. I): 99-103.

Thiengo SB, Mattos AC, Santos SB, Fernandez MA 2006. Freshwater snails and schistosomiasis mansoni in the state of Rio de Janeiro, Brazil: VI- Noroeste Fluminense Mesoregion. Mem Inst Oswaldo Cruz 101 (Suppl. I): 239-103.

Travassos L 1928. Informações sobre alguns Heterophyidae dos animais domésticos do Brasil. Ann Fac Med S Paulo 3: 1-4.

Zdzitowiecki K, Rutkowska MA 1980. The helminthofauna of bats (Chiroptera) from Cuba. III. A review of trematodes. Acta Parasitol Pol 26: 201-214.

Yamaguti S 1975. A synoptical review of life histories of digenetic trematodes of vertebrates, Keigaku Publishing Co, Tokyo, 590 pp. 